\title{
Cis/trans isomerization of fatty acids as a defence mechanism of Pseudomonas putida strains to toxic concentrations of toluene
}

\author{
Frans J. Weber, Sonja Isken and Jan A. M. de Bont \\ Author for correspondence: Frans J. Weber. Fax: +31837084978 . \\ e-mail: frans.weber@algemeen.im.wau.nl
}

Division of Industrial Microbiology, Department of Food Science,

Wageningen Agricultural

University, PO Box 8129,

6700 EV Wageningen, The Netherlands

\begin{abstract}
Defence mechanisms of three Pseudomonas putida strains growing in the presence of toluene up to $50 \%(v / v)$ were investigated. The three strains reacted to toxic concentrations of toluene by accumulating trans unsaturated fatty acids in the membrane instead of the cis isomers. The membranes of the toluene-adapted cells possessed a higher trans/cis ratio and had a higher lipidordering since the transition temperature was about 7 centigrade degrees higher compared to the non-adapted cells.
\end{abstract}

Keywords: Pseudomonas putida, trans fatty acids, two-phase system, toluene toxicity,
membrane fluidity

\section{INTRODUCTION}

Aromatic solvents like toluene, styrene and tetralin are toxic for micro-organisms even at subsaturating concentrations in water (de Smet et al., 1978; Sikkema et al., 1992). These solvents partition preferentially in the cell membrane and this excessive accumulation causes expansion of the membrane and impairment of membrane functions (Sikkema et al., 1994). Notwithstanding the clear toxicity of various aromatic solvents to most microorganisms, bacteria do exist that are able to tolerate high concentrations of such compounds in their environment. Clear examples are Pseudomonas putida IH-2000 (Inoue \& Horikoshi, 1989) and P. putida PpG1 (Shima et al., 1991) which grew in the presence of $50 \%(\mathrm{v} / \mathrm{v})$ toluene. These strains, however, were not able to metabolize toluene. Recently, two other strains have been isolated which can utilize toxic solvents as carbon and energy source. $P$. putida Idaho grew on toluene and $p$-xylene in concentrations of more than $50 \%$ (Cruden et al., 1992) and $P$. putida S12 grew on supersaturating concentrations of styrene (Weber et al., 1993).

The mechanism of this tolerance of these P. putida strains is presently unknown, but it is reasonable to expect adaptations at the level of the membrane composition. Changes in the fatty acid composition of membrane lipids may alter the partitioning of solvents in the membrane. An increase of the acyl chain length of the phospholipids from tetradecanoic to octadecanoic acid reduced the partitioning of lindane into liposomes 50 -fold (AntunesMadeira \& Madeira, 1989). Incubations of Escherichia coli with apolar solvents such as benzene and octanol resulted in increased synthesis of saturated fatty acids (Ingram,
1976; Ingram, 1977). Another adaptation mechanism has been observed in a Pseudomonas putida species growing on phenol at high concentrations (Heipieper et al., 1992). These cells adapted by converting the cis unsaturated fatty acids into the trans isomers which have a higher transition temperature and a decreased fluidity of the membrane.

In this report we describe changes in the fatty acid composition of the phospholipids of the three solventtolerant strains $P$. putida PpG1, P. putida Idaho and P. putida $\mathrm{S} 12$, in response to the presence of supersaturating concentrations of organic solvents in the growth medium.

\section{METHODS}

Organism and growth. Pseudomonas putida S12 had been isolated on styrene (Hartmans et al., 1990). P. putida Idaho (NRRL B18435) and P. putida PpG1 (ATCC 17453) were obtained from culture collections. Cells were grown in phosphate-buffered (pH 7.0) mineral salts medium (Hartmans et al., 1989) with sodium acetate $(60 \mathrm{mM})$ or glucose $(15 \mathrm{mM})$ as carbon and energy source. Cultures were incubated at $30^{\circ} \mathrm{C}$ with horizontal shaking in a water bath (160 oscillations $\mathrm{min}^{-1}$, amplitude $2 \cdot 2 \mathrm{~cm})$.

Growth in the presence of solvents. An inoculum of $5 \%$ (v/v) from an overnight culture was transferred to fresh medium. When the culture reached the exponential growth phase $\left(\mathrm{OD}_{660}\right.$ $\approx 0 \cdot 4)$ organic solvents were added. The culture bottles $(250 \mathrm{ml})$ containing $25 \mathrm{ml}$ of medium were closed with Mininert valves (Phase Separations, Waddinxveen, The Netherlands) to prevent evaporation. A partition coefficient of toluene between medium and air of 3.8 (Amoore \& Hautala, 1983) was used to calculate the toluene concentrations in the water phase.

Chemostat. Cells were grown on mineral salts medium with 
Table 1. Fatty acid composition (\%) of three toluene-tolerant $P$. putida strains grown on glucose, acetate or acetate in the presence of toluene $(1 \%, v / v)$, respectively

\begin{tabular}{|c|c|c|c|c|c|c|c|c|c|}
\hline & \multicolumn{3}{|c|}{ P. putida $\mathrm{S} 12$} & \multicolumn{3}{|c|}{ P. putida PpG1 } & \multicolumn{3}{|c|}{ P. putida Idaho } \\
\hline & Glucose & Acetate & $\begin{array}{c}\text { Acetate }+ \\
1 \% \\
\text { toluene }\end{array}$ & Glucose & Acetate & $\begin{array}{c}\text { Acetate }+ \\
1 \% \\
\text { toluene }\end{array}$ & Glucose & Acetate & $\begin{array}{c}\text { Acetate }+ \\
1 \% \\
\text { toluene }\end{array}$ \\
\hline \multicolumn{10}{|l|}{ Fatty acid } \\
\hline $16: 0$ & $35 \cdot 9$ & $31 \cdot 4$ & $31 \cdot 2$ & $30 \cdot 7$ & $34 \cdot 3$ & $34 \cdot 5$ & $39 \cdot 4$ & 38.7 & $39 \cdot 5$ \\
\hline $16: 1$ trans & $4 \cdot 7$ & $9 \cdot 6$ & $20 \cdot 6$ & $12 \cdot 5$ & $12 \cdot 3$ & 16.9 & $4 \cdot 4$ & $9 \cdot 0$ & $12 \cdot 1$ \\
\hline $16: 1$ cis & $32 \cdot 8$ & $25 \cdot 9$ & 13.5 & $23 \cdot 2$ & $20 \cdot 4$ & $9 \cdot 4$ & $18 \cdot 9$ & 16.7 & $2 \cdot 9$ \\
\hline 17 cyclo & $<1 \cdot 0$ & $6 \cdot 1$ & $5 \cdot 3$ & $1 \cdot 3$ & $3 \cdot 0$ & $7 \cdot 8$ & $3 \cdot 0$ & 3.6 & 6.5 \\
\hline $18: 0$ & $4 \cdot 2$ & $1 \cdot 4$ & $1 \cdot 3$ & $1 \cdot 4$ & 3.6 & $1 \cdot 4$ & $2 \cdot 3$ & $2 \cdot 9$ & 1.7 \\
\hline $18: 1$ trans & $1 \cdot 0$ & $3 \cdot 1$ & $10 \cdot 4$ & $1 \cdot 8$ & $1 \cdot 8$ & $7 \cdot 1$ & $4 \cdot 6$ & 8.7 & $17 \cdot 2$ \\
\hline $18: 1$ cis & $21 \cdot 4$ & $21 \cdot 3$ & $16 \cdot 9$ & $26 \cdot 7$ & $22 \cdot 4$ & $19 \cdot 4$ & $22 \cdot 0$ & $23 \cdot 9$ & $8 \cdot 5$ \\
\hline 19 cyclo & $<1 \cdot 0$ & $1 \cdot 2$ & $<1 \cdot 0$ & $1 \cdot 1$ & $2 \cdot 1$ & $3 \cdot 5$ & $5 \cdot 3$ & $4 \cdot 3$ & $11 \cdot 6$ \\
\hline \multicolumn{10}{|l|}{ Ratio } \\
\hline Sat./unsaturated & 0.67 & 0.67 & 0.62 & 0.54 & 0.76 & $0 \cdot 89$ & $1 \cdot 00$ & $0 \cdot 94$ & $1 \cdot 45$ \\
\hline trans/cis $16: 1$ & $0 \cdot 14$ & 0.37 & 1.5 & 0.54 & $0 \cdot 60$ & $1 \cdot 8$ & $0 \cdot 23$ & 0.54 & $4 \cdot 1$ \\
\hline trans/cis $18: 1$ & 0.05 & $0 \cdot 15$ & 0.62 & 0.07 & 0.08 & 0.37 & $0 \cdot 21$ & 0.36 & $2 \cdot 0$ \\
\hline
\end{tabular}

$15 \mathrm{mM}$ glucose in a fermenter with $700 \mathrm{ml}$ working volume at $30{ }^{\circ} \mathrm{C}, 350$ r.p.m. and at a dilution rate of $0 \cdot 2 \mathrm{~h}^{-1}$. Various toluene concentrations were supplied to the fermenter via the: gas phase by passing an adjustable part of the air flow through. a column $(15 \mathrm{~cm})$ of toluene which was kept at $30^{\circ} \mathrm{C}$. The total air flow was kept constant at $140 \mathrm{ml} \mathrm{min}^{-1}$.

Bacterial survival. The numbers of viable cells before and after solvents were added to exponentially growing cultures $\left(\mathrm{OD}_{660}\right.$ $\approx 0 \cdot 4$ ) or to cells harvested from steady state chemostat cultures were determined by plating $0.1 \mathrm{ml}$ of suitable dilutions in $0.8 \%$ $(\mathrm{w} / \mathrm{v})$ saline on solidified agar medium with the same growth substrate (e.g. acetate or glucose) as the liquid cultivation medium.

Fatty acid analysis. The total lipids of cells were extracted with chloroform/methanol (Bligh \& Dyer, 1959). The fatty acids were methylated using boron trifluoride/methanol according to the method of Morrison \& Smith (1964). The fatty acid methyl esters were extracted into hexane and normally analysed on a Chrompack CP9000 gas chromatograph equipped with a CP-Sil 88 WCOT fused-silica column. Fatty acid identities were confirmed by GC-MS analysis using a 5890A Hewlett/Packard gas chromatograph equipped with a CP-Sil 19CB WCOT fusedsilica capillary column; mass spectra were recorded on a 5970 series mass-selective detector with a 59822B Ionization Gauge Controller (Hewlett/Packard).

Phase transition temperature. The temperature-dependent vibrational frequency of the $\mathrm{CH}_{2}$-stretch in lipids of whole bacterial cells was measured by Fourier transform infrared spectroscopy (FTIR). FTIR measurements were carried out using a Perkin-Elmer series 1750 FTIR spectrometer equipped with a 7500 data station, as described by Crowe et al. (1989). Exponentially growing cells were harvested and washed twice with water. The pellet was placed between two $\mathrm{CaF}_{2}$ windows. The sample was cooled to $-10{ }^{\circ} \mathrm{C}$ and slowly heated; spectra were recorded after every stepwise increase ( 2 to 3 centigrade degrees) in temperature.

\section{RESULTS}

\section{Fatty acid composition}

The three solvent-resistant strains, $P$. putida PpG1, P. putida Idaho and $P$. putida S12 were grown in mineral medium containing either glucose, acetate, or acetate in the presence of toluene $(1 \%, v / v)$. Exponentially growing cells from these cultures were harvested, washed and the fatty acid profiles were determined (Table 1).

When glucose-grown $P$. putida $\mathrm{S} 12$ cells were compared to acetate-grown cells, an increase in the amount of trans and a decrease in the cis unsaturated fatty acids was seen. A further increase in the trans/cis ratio was observed when $P$. putida S12 cells were grown on acetate in the presence of toluene $(1 \%)$. The acetate-grown cells also had a higher percentage of cyclopropane fatty acids when compared to glucose-grown cells. However, the presence of toluene had no effect on these cyclopropane fatty acids. Similarly, in two other solvent-tolerant strains, $P$. putida PpG1 and P. putida Idaho, high trans/cis ratios were observed when grown in the presence of high toluene concentrations.

\section{Stability of the adaptation}

Subsequently, we determined whether the observed changes in fatty acid profiles, as dependent on growth conditions, were reversible. $P$. putida $\mathrm{S} 12$ grown on acetate in the presence of $1 \%$ toluene was used to inoculate $(1 \%)$ acetate and glucose medium without solvents. The fatty acid composition of the cells grown on acetate was almost identical to the fatty acid composition of the parent culture grown in the presence of toluene. However, a decrease in the trans/cis ratio was observed, when grown on glucose (Table 2). 
Table 2. Fatty acid composition (\%) of toluene-adapted $P$. putida $\$ 12$ grown in the absence of toluene for about 100 generations on glucose or acetate, respectively

\begin{tabular}{|lcc|}
\hline & Glucose & Acetate \\
\hline Fatty acid & & \\
$16: 0$ & $38 \cdot 4$ & $32 \cdot 5$ \\
$16: 1$ trans & $11 \cdot 5$ & $25 \cdot 2$ \\
$16: 1$ cis & $19 \cdot 1$ & $12 \cdot 2$ \\
17 cyclo & $3 \cdot 1$ & $2 \cdot 8$ \\
$18: 0$ & $2 \cdot 8$ & $2 \cdot 1$ \\
$18: 1$ trans & $2 \cdot 9$ & $6 \cdot 9$ \\
$18: 1$ cis & $22 \cdot 3$ & $16 \cdot 9$ \\
19 cyclo & $<1 \cdot 0$ & $1 \cdot 0$ \\
Ratio & & \\
Sat./unsaturated & $0 \cdot 79$ & $0 \cdot 63$ \\
trans/cis $16: 1$ & $0 \cdot 60$ & $2 \cdot 1$ \\
trans/cis $18: 1$ & $0 \cdot 13$ & $0 \cdot 41$ \\
\hline
\end{tabular}

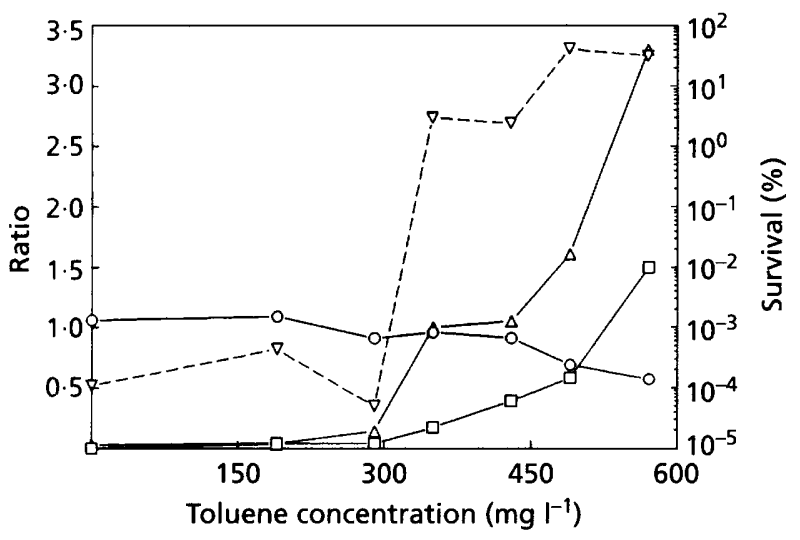

Fig. 1. Effect of toluene on the fatty acid composition of $P$. putida $\mathrm{S} 12$ and on survival of cells given a shock addition of toluene. Cells were grown in a glucose-limited chemostat in the presence of various toluene concentrations. Ratio $(-)$ of saturated/unsaturated fatty acids $(O)$, trans/cis ratio of hexadecenoic acid $(\triangle)$ and octadecenoic acid $(\square)$ and the percentage survivors (--) $1 \mathrm{~h}$ after the extra addition of toluene $(1 \%, v / v)(\nabla)$.

\section{Subsaturating concentrations of toluene}

Toluene concentrations below the maximum solubility in water $\left(640 \mathrm{mg} \mathrm{l}^{-1}\right.$ at $30^{\circ} \mathrm{C}$ ) (Bohon \& Claussen, 1951) also slowed the growth of $P$. putida S12 on glucose or acetate medium. A toluene concentration of about $350 \mathrm{mg} \mathrm{l}^{-1}$ reduced the growth rate to one-half of the maximum. When these cells were transferred to fresh medium with the same toluene concentration, no growth inhibition was observed.

The effect of toluene on the fatty acid composition of $P$. putida $\mathrm{S} 12$ was also determined by growing the organism

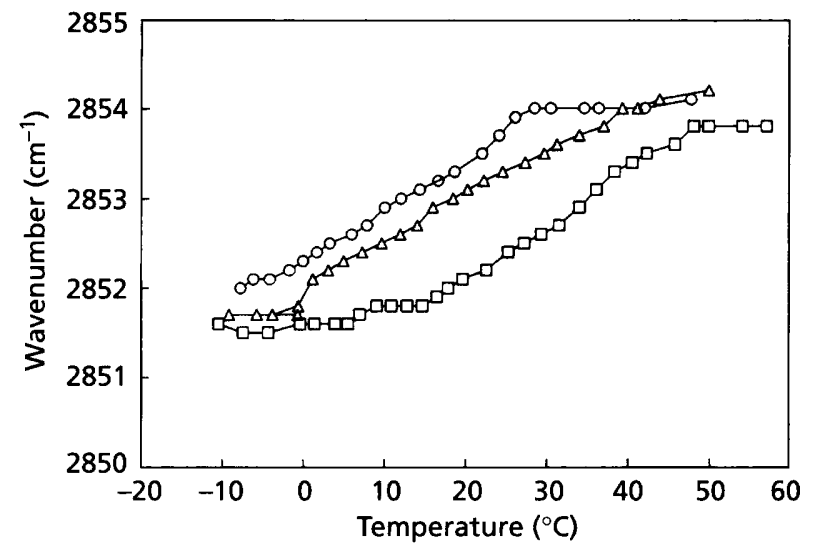

Fig. 2. Phase transition melting temperature of $P$. putida $\$ 12$ grown on glucose $(O)$, acetate $(\triangle)$ and acetate medium containing $400 \mathrm{mg}$ toluene $\mathrm{I}^{-1}(\square)$, respectively. Wavenumbers of the $\mathrm{CH}_{2}$ symmetric stretch in the lipids were measured using FTIR spectroscopy at various temperatures.

in a glucose-limited chemostat at a dilution rate of $0 \cdot 2 \mathrm{~h}^{-1}$. Various subsaturating toluene concentrations were applied to the fermenter via the gas phase. The fatty acid composition of the cultures was determined after a steadystate was reached in the chemostat. Toluene concentrations below $300 \mathrm{mg} \mathrm{l}^{-\mathbf{1}}$ in the water phase did not result in changes in the fatty acid composition. However, substantial changes in the trans/cis ratio of the unsaturated fatty acids were observed in cells grown in the presence of higher toluene concentrations (Fig. 1). The steady-state chemostat cultures were also used to determine the effect on cell viability of a 'shock' addition of toluene $(1 \%)$. Only a small number of survivors were recorded in cultures grown in the presence of less than $300 \mathrm{mg}$ toluene $1^{-1}$. However, when grown in the presence of more than $300 \mathrm{mg}$ toluene $\mathrm{l}^{-1}$, a high percentage of cells survived this addition of toluene.

\section{Phase transition temperature}

Fatty acids undergoing melting from gel to liquid phase show an adsorption shift of 2-4 wavenumbers in the infrared spectrum (Cameron \& Dluhy, 1987). The symmetric vibration band of $\mathrm{CH}_{2}$ groups at a frequency around $2850 \mathrm{~cm}^{-1}$ was measured using FTIR spectroscopy. This adsorption maximum was determined at different temperatures for $P$. putida $\mathrm{S} 12$ grown on glucose, acetate or acetate medium containing $400 \mathrm{mg}$ toluene $\mathrm{l}^{-1}$, respectively. In Fig. 2 it can be seen that cells grown in the presence of toluene possess a lipid melting temperature which is about 7 centigrade degrees higher than in cells grown in the absence of toluene.

\section{DISCUSSION}

Previously we have isolated 14 bacteria on subsaturating concentrations of styrene as sole carbon and energy source (Hartmans et al., 1990). These bacteria were 
thought not to grow on supersaturating concentrations of styrene, as these high styrene concentrations were expected to be toxic (de Smet et al., 1978; Sikkema et al., 1994). However, one of the selected strains, P. putida S12. eventually grew on styrene at concentrations of more thar. $50 \%$ after a long lag-phase (Weber et al., 1993).

In the present investigation, significant changes in the fatty acid profiles of solvent-adapted strains have been. observed. P. putida S12 and two other solvent-tolerant strains responded to the presence of $1 \%$ toluene by increasing the amount of trans fatty acids and by decreasing the corresponding cis isomer. This adaptation. in $P$. putida $\mathrm{S} 12$, occurred not only at supersaturating concentrations but also at subsaturating concentrations of toluene in water. No effects were seen below $300 \mathrm{mg}$ toluene $\mathrm{l}^{-1}$, but above $300 \mathrm{mg} \mathrm{l}^{-1}$ the trans/cis isomer ratio of the cells increased dramatically. Cells having a high trans/cis isomer ratio were well equipped to survive: 'shock' additions of toluene (1\%).

The cis/trans isomerization as an adaptation mechanism in $P$. putida $\mathrm{S} 12$ is quite remarkable as most bacteria adapt to membrane-active compounds by changing the saturation index of their lipids (Ingram, 1976, 1977; Ingram \& Buttke, 1984; Keweloh et al., 1990). Although 15 years ago trans monounsaturated fatty acids were regarded as non-natural fatty acids (Lehninger, 1977), over the last 10 years trans fatty acids in bacteria have been reported in, for instance Arcobacter cryaerophila (Moss \& Daneshvar, 1992), P. aeruginosa (de Andres et al., 1991), P. atlantica (Guckert et al., 1987), P. putida (Heipieper et al., 1992), Vibrio cholerae (Guckert et al., 1986) and other Vibric species (Okuyama et al., 1990), a marine isolate (Gillan el al., 1981) and in methane-utilizing bacteria (Makula, 1978). Recently, a cis/trans isomerization has been observed as an adaptation mechanism of a $P$. putida strain to toxic phenol concentrations (Heipieper et al., 1992). From our results it now appears that this defence mechanism is widespread in $P$. putida species.

The trans isomer has a steric configuration which is similar to that of saturated fatty acids. The cis-isomer has a kink in the acyl-chain of the fatty acids, which causes steric hindrance and results in a membrane with a higher fluidity. Studies with Acboleplasma laidlawii membranes enriched with exogenously supplied fatty acids have shown that the phase transition temperature between membranes containing about $80 \%$ cis or trans octadecenoic acid, respectively, differ about 45 centigrade degrees (Macdonald et al., 1985). In the toluene-adapted strain possessing a high trans/cis ratio, the transition temperature of the membrane in vivo was approximately 7 centigrade degrees higher compared to the non-adapted cells. This provides the cell with a mechanism to compensate for loss of membrane integrity as a result of the accumulation of lipophilic compounds. Furthermore, an increased lipid ordering also opposes partitioning of lipophilic compounds in the membrane (Antunes-Madeira \& Madeira, 1989).

Apart from an increase in the trans/cis ratio of the unsaturated fatty acids, an increase in the amount of cyclopropane fatty acids was observed in acetate-grown cells when compared to glucose-grown cells. The lipids of acetate-grown $P$. putida S12 consisted of about $6 \%$ cyclopropane fatty acids, whereas glucose-grown cells did not contain these fatty acids. However, adaptation to toluene either in batch or in chemostat cultures did not enhance the level of cyclopropane fatty acids.

Growth of P. putida S12 in batch-cultures in the presence of supersaturating toluene concentrations was only observed when using toxic concentrations of acetate or propionate as carbon source (Weber et al., 1993). At $60 \mathrm{mM}$ acetate $(\mathrm{pH} 7 \cdot 0)$, about $0.3 \mathrm{mM}$ of the undissociated acetic acid will be present in the medium. Results of Sheu \& Freese (1972) suggest that these low concentrations of acetic acid are membrane-active. Acetateadapted cells had an increased trans/cis ratio of the monounsaturated fatty acids. As a result, cells from such cultures had a higher degree of lipid ordering in the membrane and consequently these cells were able to further adapt and grow in the presence of toluene. Nakajima et al. (1992) and Aono et al. (1992) have shown that toluene-resistant bacteria can be isolated effectively by first adapting bacteria to the presence of a second phase of the less toxic solvent, xylene. Pre-adaptation of cells to less toxic compounds (acetate, xylene) or to subsaturating concentrations of toxic solvents (toluene) seems to be an effective technique to isolate solvent-tolerant microorganisms.

P. putida $\mathrm{S} 12$ cells possessing a high trans/cis isomer ratio after growth on acetate medium containing toluene, did not revert back to normal fatty acid content upon several generations growth without toluene. This response seems to be quite unusual, but these cells were grown on a medium with an acetate concentration $(60 \mathrm{mM})$ which is normally toxic for the cells. Apparently, the modification in the fatty acid composition induced by toluene, is of benefit for the cells to grow in the presence of toxic acetate concentrations. Upon removal of acetate, a normal fatty acid composition was observed, indicating that the trans/cis isomerization is an adaptation mechanism and not a mutation.

The present investigation has focussed only on one possible defence mechanism of $P$. putida strains to toxic solvents. Further investigations will be necessary to determine whether trans/cis isomerization of the fatty acids is an important factor in gaining resistance or that other, as yet undiscovered adaptations are of primary importance. In this respect it will be worthwhile to consider the known effects of alcohols on microorganisms including changed protein/lipid ratios or changes in the phospholipid classes (Ingram \& Buttke, 1984).

\section{ACKNOWLEDGEMENTS}

We thank Hermann J. Heipieper for helpful discussion during the preparation of the manuscript; C. J. Teunis, Department of Organic Chemistry (Agricultural University Wageningen) for 
GC-MS analyses; and Dr. F. A. Hoekstra, Department of Plant Physiology (Agricultural University Wageningen) for assistance with phase transition temperature determinations.

\section{REFERENCES}

Amoore, J. E. \& Hautala, E. (1983). Odor as an aid to chemical safety: odor thresholds compared with threshold limit values and volatilities for 214 industrial chemicals in air and water dilution. $J$ Appl Toxicol 3, 272-290.

de Andres, C., Espuny, M. J., Robert, M., Mercade, M. E., Manresa, A. \& Guinea, J. (1991). Cellular lipid accumulation by Pseudomonas aeruginosa 44T1. Appl Microbiol Biotechnol 35, 813-816.

Antunes-Madeira, M. C. \& Madeira, V. M. C. (1989). Membrane fluidity as affected by the insecticide lindane. Biocbim Biopbys Acta 982, 161-166.

Aono, R., Ito, M., Inoue, A. \& Horikoshi, K. (1992). Isolation of novel toluene-tolerant strain of Pseudomonas aeruginosa. Biosci Biotechnol Biochem 1, 145-146.

Bligh, E. G. \& Dyer, W. J. (1959). A rapid method of total lipid extraction and purification. Can J Biochem Pbysiol 37, 911-917.

Bohon, R. L. \& Claussen, W. F. (1951). The solubility of aromatic hydrocarbons in water. J Am Chem Soc 73, 1571-1578.

Cameron, D. G. \& Dluhy, R. A. (1987). FTIR studies of molecular conformations in biological membranes. In Spectroscopy in the Medical Sciences, pp. 53-86. Edited by R. M. Gendreau, Boca Raton: CRC Press.

Crowe, J. H., Hoekstra, F. A., Crowe, L. M., Anchordoguy, T. J. \& Drobnis, J. (1989). Lipid phase transitions measured in intact cells with Fourier transform infrared spectroscopy. Cryobiology 26, 76-84.

Cruden, D. L., Wolfram, J. H., Rogers, R. D. \& Gibson, D. T. (1992). Physiological properties of a Pseudomonas strain which grows with $p$-xylene in a two-phase (organic-aqueous) medium. Appl Environ Microbiol 58, 2723-2729.

Gillan, F. T., Johns, R. B., Verheyen, T. V., Volkman, J. K. \& Bavor, H. J. (1981). Trans-monounsaturated acids in marine bacterial isolate. Appl Environ Microbiol 41, 849-856.

Guckert, J. B., Hood, M. A. \& White, D. C. (1986). Phospholipid ester-linked fatty acid profile changes during nutrient deprivation of Vibrio cholerae: increases in the trans/cis ratio and proportions of cyclopropyl fatty acids. Appl Environ Microbiol 52, 794-801.

Guckert, J. B., Ringelberg, D. B. \& White, D. C. (1987). Biosynthesis of trans fatty acids from acetate in the bacterium Pseudomonas atlantica. Can J Microbiol 33, 748-754.

Hartmans, S., Smits, J. P., van der Werf, M. J., Volkering, F. \& de Bont, J. A. M. (1989). Metabolism of styrene oxide and 2phenylethanol in the styrene-degrading Xanthobacter strain 124X. Appl Environ Microbiol 55, 2850-2855.

Hartmans, S., van der Werf, M. J. \& de Bont, J. A. M. (1990). Bacterial degradation of styrene involving a novel flavin adenine dinucleotide-dependent styrene monooxygenase. Appl Environ Microbiol 56, 1347-1251.

Heipieper, H.-J., Diefenbach, R. \& Keweloh, H. (1992). Conversion of $c$ is unsaturated fatty acids to trans, a possible mechanism for the protection of phenol-degrading Pseudomonas putida P8 from substrate toxicity. Appl Environ Microbiol 58, 1847-1852.
Ingram, L. O. (1976). Adaptation of membrane lipids to alcohols. $J$ Bacteriol 125, 670-678.

Ingram, L. O. (1977). Changes in lipid composition of Escherichia coli resulting from growth with organic solvents and with food additives. Appl Environ Microbiol 33, 1233-1236.

Ingram, L. O. \& Buttke, T. M. (1984). Effects of alcohols on microorganisms. Adv Microb Physiol 25, 254-300.

Inoue, A. \& Horikoshi, K. (1989). A Pseudomonas thrives in high concentrations of toluene. Nature 338, 264-266.

Keweloh, H., Weyrauch, G. \& Rehm, H.-J. (1990). Phenol-induced membrane changes in free and immobilized Escherichia coli. Appl Microbiol Biotechnol 33, 66-71.

Lehninger, A. L. (1977). Biochemistry. New York: Worth Publishers. Macdonald, P. M., Sykesm, B. D. \& McElhaney, R. N. (1985). Fluorin-19 nuclear magnetic resonance studies of lipid fatty acyl chain order and dynamics in Acholoplasma laidlawii B membranes. A direct comparison of the effects of cis and trans cyclopropane ring and double-bond substituents on oriental order. Biochemistry 24, 4651-4659.

Makula, R. A. (1978). Phospholipid composition of methaneutilizing bacteria. J Bacteriol 134, 771-777.

Morrison, W. R. \& Smith, L. M. (1964). Preparation of fatty acid methyl esters and dimethylacetals from lipids with boron fluoridemethanol. J Lipid Res 5, 600-608.

Moss, C. W. \& Daneshvar, M. I. (1992). Identification of some uncommon monounsaturated fatty acids of bacteria. J Clin Microbiol 30, 2511-2512.

Nakajima, H., Konayashi, H., Aono, R. \& Horikoshi, K. (1992). Effective isolation and identification of toluene-tolerant Pseudomonas strains. Biosci Biotechnol Biochem 56, 1872-1873.

Okuyama, H., Sasaki, S., Higaski, S. \& Murata, N. (1990). A transunsaturated fatty acid in a psychrophilic bacterium, Vibrio sp. strain ABE-1. J Bacteriol 172, 3515-3518.

Sheu, C. W. \& Freese, E. (1972). Effects of fatty acids on growth and envelope proteins of Bacillus subtilus. J Bacteriol 111, 516-524.

Shima, H., Kudo, T. \& Horikoshi, K. (1991). Isolation of tolueneresistant mutants from Pseudomonas putida PpG1 (ATCC 17453). Agric Biol Chem 55, 1197-1199.

Sikkema, J., Poolman, B., Konings, W. N. \& de Bont, J. A. M. (1992). Effects of the membrane action of tetralin on the functional and structural properties of artificial and bacterial membranes. $J$ Bacteriol 174, 2986-2992.

Sikkema, J., de Bont, J. A. M. \& Poolman, B. (1994). Interaction of cyclic hydrocarbons with biological membranes. J Biol Chem 269 , 8022-8028.

de Smet, M. J., Kingma, J. \& Witholt, B. (1978). The effect of toluene on the structure and permeability of the outer and cytoplasmic membranes of Escherichia coli. Biochim Biophys Acta 506, 64-80.

Weber, F. J., Ooykaas, L. P., Schemen, R. M. W., Hartmans, S. \& de Bont, J. A. M. (1993). Adaptation of Pseudomonas putida $\mathrm{S} 12$ to high concentrations of styrene and other organic solvents. Appl Environ Microbiol 59, 3502-3504.

Received 22 December 1993; revised 14 February 1994; accepted 24 March 1994. 